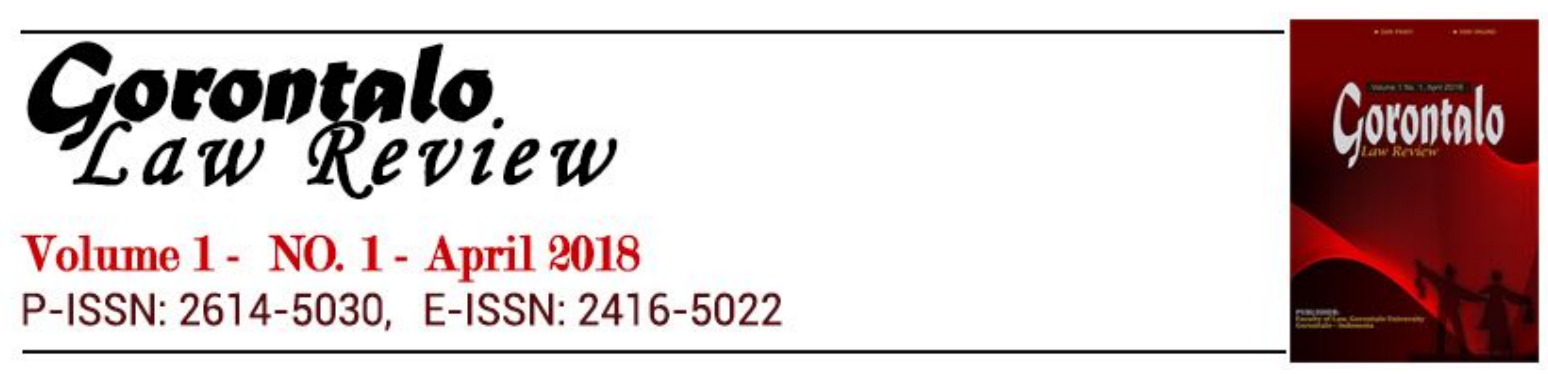

\title{
Perlindungan Hukum Terhadap Tenaga Pendidik
}

\author{
Leni Dwi Nurmala \\ Ilmu Hukum, Fakultas Hukum Universitas Gorontalo \\ email: lenitsaina@gmail.com
}

\begin{abstract}
One form of protection given to teachers in performing their professional duties is legal protection. This legal protection includes legal protection against acts of violence, threats, discriminatory treatment, intimidation or unfair treatment of learners, parents of learners, society, bureaucracy or other parties. One of the educational problems faced by schools in general is the violence of teachers towards students who still often occur in the school environment.
\end{abstract}

Keywords: violence, teachers

\section{PENDAHULUAN}

Beberapa waktu lalu dunia pendidikan di kejutkan dengan terjadinya penganiayaan terhadap tenaga pendidik, baik yang hanya menimbulkan luka maupun sampai akibat kematian. Sangat disayangkan penganiayaan seorang murid terhadap guru di Sampang, Jatim, yang berujung kematian korban, seorang siswa tega melakukan kekerasan fisik terhadap gurunya hingga meninggal dunia lantaran mendapat teguran dari gurunya. Belum hilang ingatan tentang berita meninggalnya seorang guru di Madura, tidak lama kemudian terjadilah Peristiwa Kekerasan dan penganiayaan fisik yang dilakukan oleh salah satu orangtua walimurid yang terjadi kepada Kepala Sekolah SMP Negeri 4 Lolak, Kabupaten Bolaang Mangondow, Propinsi Sulawesi Utara, di Sulawesi Utara. Jelas bahwa apa yang terjadi dari 2 contoh diatas adalah murni tindak pidana penganiayaan.

Belakangan ini sering terdengar tindak kekerasan yang dilakukan oleh orang tua murid terhadap guru ataupun kekerasan yang dilakukan oleh murid terhadap gurunya. Keadaan ini tidak pernah terdengar dimasa lalu, tetapi beberapa tahun terakhir marak terjadi kekerasan yang dilakukan oleh orangtua siswa kepada guru. Kedaan ini menunjukan bahwa ada pergeseran moral yang terjadi pada masyarakat, serta keprofesian guru yang semakin tidak ada harganya.

Semua kejadian diatas menjadi bukti bahwa keprofesin guru, tenaga pendidik, dosen dan lain-lain sangat di pandang rendah oleh sebagian masyarakat. Saat ini ketika guru melakukan tindakan pendisiplinan itu artinya guru berada dalam masalah besar, yang mungkin saja kejadian-kejadian tersebut akan terulang lagi. Sosialisasi hak dan kewajiban guru tenaga pendidik, dosen dan lain-lain dalam mendidik dan mendisiplinkan murid/siswa harus 
lebih ditingkatkan lagi, bukan hanya guru yang faham akan hak dan kewajiban mendidik, akan tetapi siswa dan orang tuapun harus sama-sama faham dan mengerti. Mudah-mudahan kekerasan terhadap guru tidak terjadi lagi.Perlindungan hukum terhadap guru diakui memang masih lemah. Ketika guru terkena masalah hukum khususnya yang berkaitan dengan tugasnya sebagai guru,tenaga pendidik, dosen dan lain-lain seolah harus berjuang sendiri.

\section{KAJIAN TEORI}

\subsection{Perlindungan Hukum}

Perlindungan hukum adalah segala upaya pemenuhan hak dan pemberian bantuan untuk memberikan rasa aman kepada saksi dan/atau korban, perlindungan hukum korban kejahatan sebagai bagian dari perlindungan masyarakat, dapat diwujudkan dalam berbagai bentuk, seperti melalui pemberian restitusi, kompensasi, pelayanan medis, dan bantuan hukum.

Perlindungan hukum yang diberikan kepada subyek hukum ke dalam bentuk perangkat baik yang bersifat preventif maupun yang bersifat represif, baik yang lisan maupun yang tertulis. Dengan kata lain dapat dikatakan bahwa perlindungan hukum sebagai suatu gambaran tersendiri dari fungsi hukum itu sendiri, yang memiliki konsep bahwa hukum memberikan suatu keadilan, ketertiban, kepastian, kemanfaatan dan kedamaian.

Pengertian di atas mengundang beberapa ahli untuk mengungkapkan pendapatnya mengenai pengertian dari perlindunganhukum diantaranya :

1. Menurut Satjipto Raharjo mendefinisikan Perlindungan Hukum adalah memberikan pengayoman kepada hak asasi manusia yang dirugikan orang lain dan perlindungan tersebut diberikan kepada masyarakat agar mereka dapat menikmati semua hak-hak yang diberikan oleh hukum.

2. Menurut Philipus M. Hadjon berpendapat bahwa Perlindungan Hukum adalahperlindungan akan harkat dan martabat, serta pengakuan terhadap hak-hak asasi manusia yang dimiliki oleh subyek hukum berdasarkan ketentuan hukum dari kesewenangan.

3. Menurut CST Kansil Perlindungan Hukum adalah berbagai upaya hukum yang harus diberikan oleh aparat penegak hukum untuk memberikan rasa aman, baik secara pikiran maupun fisik dari gangguan dan berbagai ancaman dari pihak manapun.

4. Menurut Philipus M. Hadjon Perlindungan Hukum adalah Sebagai kumpulan peraturan atau kaidah yang akan dapat melindungi suatu hal dari hal lainnya. Berkaitan dengan konsumen, berarti hukum memberikan perlindungan terhadap hak-hak pelanggan dari sesuatu yang mengakibatkan tidak terpenuhinya hak-hak tersebut.

Dalam menjalankan dan memberikan perlindungan hukum dibutuhkannya suatu tempat atau wadah dalam pelaksanaannya yang sering di 
sebut dengan sarana perlindungan hukum, sarana perlindungan hukum dibagi menjadi dua macam yang dapat dipahami, sebagai berikut :

a. Sarana Perlindungan Hukum Preventif. Pada perlindungan hukum preventif ini, subyek hukum diberikan kesempatan untuk mengajukan keberatan atau pendapatnya sebelum suatu keputusan pemerintah mendapat bentuk yang definitif. Tujuannya adalah mencegah terjadinya sengketa. Perlindungan hukum preventif sangat besar artinya bagi tindak pemerintahan yang didasarkan pada kebebasan bertindak karena dengan adanya perlindungan hukum yang preventif pemerintah terdorong untuk bersifat hati-hati dalam mengambil keputusan yang didasarkan pada diskresi. Di Indonesia belum ada pengaturan khusus mengenai perlindungan hukum preventif.

b. Sarana Perlindungan Hukum Represif. Perlindungan hukum yang represif bertujuan untuk menyelesaikan sengketa. Penanganan perlindungan hukum oleh Pengadilan Umum dan Peradilan Administrasi di Indonesia termasuk kategori perlindungan hukum ini. Prinsip perlindungan hukum terhadap tindakan pemerintah bertumpu dan bersumber dari konsep tentang pengakuan dan perlindungan terhadap hak-hak asasi manusia.

2.2 Tinjauan tentang Tenaga Pendidik

Pendidik merupakan tenaga profesional yang bertugas merencanakan dan melaksanakan proses pembelajaran, menilai hasil pembelajaran, melakukan pembimbingan dan pelatihan, serta melakukan penelitian dan pengabdian kepada masyarakat, terutama bagi pendidik pada perguruan tinggi. (UU No.20 THN 2003, PSL 39 (2)): Tenaga Kependidikan yang berkualifikasi sebagai guru, dosen, konselor, pamong belajar, widyaiswara, tutor, instruktur, fasilitator, dan sebutan lain yang sesuai dengan kekhususannya, serta berpartisipasi dalam menyelenggarakan pendidikan. (UU No. 20 tahun 2003 pasal 1 (BAB 1 Ketentuan umum).

Adapun tugas pendidik terdiri dari:

a. tenaga profesional

b. merencanakan pembelajaran.

c. melaksanakan pembelajaran.

d. menilai hasil pembelajaran.

e. membimbing

f. melatih

g. meniliti

h. mengabdi kepada masyarakat.

Pendidik diantaranya ada:

a. guru

b. dosen

c. tutor

d. instruktur

e. Pamong belajar

f. konselor 

g. widyaiswara
h. fasilitator
i. Penguji

\section{METODE PENELITIAN}

Metode pendekatan yang digunakan dalam penelitian ini adalah pendekatan yuridis normatif, yaitu dengan menggunakan teori-teori serta pendapat para sarjana dengan melakukan analisa terhadap ketentuanketentuan yang berkaitan dengan permasalahan yang akan di bahas dan ditelaah.

Untuk mendapatkan data-data yang berkaitan dengan masalah yang diteliti, penulis menggunakan jenis penelitian deskriptif dengan bahan utama penelitian bersumberkan pada kepustakaan (library research), yaitu: proses penulisan yang dilakukan dengan cara mempelajari buku-buku atau literaturliteratur yang berkaitan dengan permasalahan yang diteliti dari perpustakaan.

Untuk memperoleh data-data yang diperlukan sesuai tema penelitian, maka penelitian ini menggunakan sumber data dari:

1. Sumber data primer, yaitu : Undang-Undang No. 14 tahun 2005 tentang Guru dan Dosen, Undang-Undang Perlindungan Anak Nomor 35 Tahun 2014 Perubahan atas undang-undang Nomor 23 tahun 2002 tentang Perlindungan Anak, Undang-Undang Nomor 11 Tahun 2012 tentang sistem peradilan pidana anak, PP (Peraturan Pemerintah) Nomor 74 Tahun 2008dan perundang-undangan lainnya yang berkaitan dengan tema penelitian.

2. Sumber data sekunder, yaitu : buku-buku litelatur, jurnal, karya ilmiah yang berkaitan dengan tema penelitian.

3. Sumber data tersier, yaitu : keterangan-keterangan yang berkaitan dengan sumber data primer dan sekunder, baik di surat kabar maupun di media elektronik semisal berita dan informasi dari internet.

Adapun teknik Pengumpulan data Studi kepustakaan merupakan metode tunggal yang dibutuhkan dalam penelitian hukum normatif. Yang disebut juga sebagai penelitian kepustakaan atau atau studi dokumen, karena penelitian ini dilakukan atau ditujukan hanya pada peraturan-peraturan yang tertulis atau bahan-bahan hukum lain. Penelitian kepustakaan atau studi dokumen disebabkan penelitian ini lebih banyak dilakukan terhadap data yang bersifat sekunder yang ada di perpustakaan. Termasuk dalam data sekunder meliputi buku-buku, buku-buku harian, surat-surat pribadi dan dokumen-dokumen dari pemerintah. Untuk mengumpulkan data yang dibutuhkan, penulis menggunakan tehnik yakni Dokumentasi . Metode ini berguna untuk mencari data mengenai hal-hal yang variabel yang berupa catatan, buku-buku, surat kabar, majalah dan penelusuran media internet. Data-data yang terkumpul di analisa deskripsi (deskriptif analis).Secara harfiyah, metode deskriptif adalah metode penelitian untuk membuat gambaran mengenai situasi atau kejadian kemudian menguraikannya dalam bentuk analisis. 


\section{HASIL DAN PEMBAHASAN}

Saat ini profesi guru, tenaga pendidik, dosen dan lain-lain dihadapkan pada tantangan yang semakin kompleks, seiring dengan adanya perubahan cara pandang masyarakat yang secara sadar terpengaruh oleh doktrin perlindungan hukum terhadap anak, termasuk anak didik.Namun di sisi lain, perlindungan hukum terhadap profesi guru juga harus diperhatikan.Persoalannya adalah hingga saat ini belum peraturan pelaksanaan yang secara teknis operasional mengatur berbagai macam perlindungan terhadap guru, termasuk perlindungan hukumnya. Akibatnya, ketika dihadapkan pada kasus hukum tertentu, posisi guru acapkali menjadi sangat lemah. Dalam kasus-kasus tertentu, guru selain diadukan sebagai pelaku kekerasan terhadap siswa, dalam beberapa kasus justru menjadikan guru sebagai korban kekerasan dari siswa dan/atau orang tua siswa.

Undang-undang Nomor 14 Tahun 2005 tentang Guru dan Dosen pasal 7 ayat (1) huruf $\mathrm{h}$ mengamanatkan bahwa guru harus memiliki jaminan perlindungan hukum dalam melaksanakan tugas keprofesionalan. Selanjutnya pada pasal 39 secara rinci dinyatakan:

a. Pemerintah, pemerintah daerah, masyarakat, organisasi profesi, dan/atau satuan pendidikan wajib memberikan perlindungan terhadap guru dalam pelaksanaan tugas.

b. Perlindungan sebagaimana dimaksud pada ayat (1) meliputi perlindungan hukum, perlindungan profesi, serta perlindungan keselamatan dan kesehatan kerja.

c. Perlindungan hukum sebagaimana dimaksud pada ayat (2) mencakup perlindungan hukum terhadap tindak kekerasan, ancaman, perlakuan diskriminatif, intimidasi, atau perlakuan tidak adil dari pihak peserta didik, orang tua peserta didik, masyarakat, birokrasi, atau pihak lain.

d. Perlindungan profesi sebagaimana dimaksud pada ayat (2) mencakup perlindungan terhadap pemutusan hubungan kerja yang tidak sesuai dengan peraturan perundangundangan, pemberian imbalan yang tidak wajar, pembatasan dalam menyampaikan pandangan, pelecehanterhadap profesi, dan pembatasan/pelarangan lain yang dapat menghambat guru dalam melaksanakan tugas.

e. Perlindungan keselamatan dan kesehatan kerja sebagaimana dimaksud pada ayat (2) mencakup perlindungan terhadap risiko gangguan keamanan kerja, kecelakaan kerja, kebakaran pada waktu kerja, bencana alam, kesehatan lingkungan kerja, dan/atau risiko lain.

Mengenali prilaku brutal anak didik di sekolah berawal, dari bagaimana anak didik tersebut didik oleh orang tuanya dirumah. Bagaimana bimbingan orang tua menanamkan akhlak atau budi pekerti anaknya di rumah, bagaimana pergaulan anak anak di lingkungannya rumah dan sekolah yang membentuk anak itu menjadi brutal. Kurangnya penanaman akhlak orang tua terhadap anaknya mempengaruhi prilaku anak di rumah, dan di masyarakat serta 
bagaimana guru memberikan contoh berprilaku disekolah. Prilaku kekerasan yang terbentuk oleh anak didik di sekolah tentunya tidak ada keseimbangan antara pendidikan intelektual dan budi pekerti atau ahlak. Kurangnya pendidikan ahlak atau budipekerti dalam proses belajar mengajar di sekolah serta kurang terbentuknya pola asuh yang membentuk karakter murid dengan metode rasa saling asah asih , asuh dan saling hormat menghormati memungkinkan prilaku brutal anak.

Penganiayaan guru oleh siswanya tentunya tidak sebentar prosesnya. Tidak adanya wibawa guru dimata muridnya dan terbentuknya pribadi yang tidak memiliki rasa hormat terhadap terhadap gurunya karena orientasi belajar hanya mengarah ke pembentukan kecerdasan belaka akan mendorong anak tidak memiliki rasa hormat kepada gurunya, apalagi sianak sering melihat prilaku guru yang tidak terpuji dan sering melecehkan muridnya tentu menambah kebencian murid terhadap guru. Walau tanggung jawab pendidikan ada di pundak gutu, Bagaimanapun juga orang berperan penting mendidik anaknya di rumah, karena interaksi anak dan orang tua di rumah frekuensinya lebih banyak. Pembentukan karakter anak menjadi anak yang pintar dan memiliki ahlak yang mulia sangat tergantung sekali orang tua memberikan contoh di rumah, Orang tua banyak yang tidak menyadari bahwa pendidikan sekolah hanya meningkatkan nilai akademis, sedangkan pembentukan sikap , mental dan moral anak sangat kutang, kekuarangan bidang bidang inilah yang seharusnya dilengkapi oleh orang tua dirumah.

Pendidikan moral dan pembentukan sikap sebagai orang yang terpelajar tentunya diperlukan dalam pendidikan di sekolah, seperti kedisiplinan, taat pada aturan, menghormati guru dan membentuk pribadi yang berkarakter mulya, bukan membentuk karakter yang liar. Begitupun para guru harus mampu mencontohkan nilai nilai pendidikan yang ada, sehingga apa yang diajarkan selaras dengan prilakunya seningga bisa menjadi panutan murid muridnya. Dan tenunya dalam proses pendidikan ada reward and punishment dalam pendidikan. Bagi yang melakukan pelanggaran tentunya harus mendapatkan hukuman terhadap kesalahan yang dilakukannya.

Jika memang terjadi kekerasan ataupun penganiayaan terhadap guru yang dilakukan oleh murid, maka terhadap murid tersebut haruslah diselesaikan melalui jalur hukum. Hal ini dilakukan agar tidak terulang dikemudian hari oleh lainnya.

Jika murid yang melakukan kekerasan terhadap gurunya ini masih berusia kurang dari 18 tahun namun lebih dari 12 tahun sehingga masih digolongkan sebagai anak sebagaimana yang dimaksud dalam Pasal 1 angka 1 Undang-Undang Nomor 35 Tahun 2014 tentang Perubahan Atas UndangUndang Nomor 23 Tahun 2002 tentang Perlindungan Anak ("UU 35/2014").

Tindakan peserta didik/murid ini yang melakukan kekerasan kepada gurunya dengan ini dapat dikenakan pidana atas dasar penganiayaan. Namun, pidana penjara yang dapat dijatuhkan kepada Anak, berdasarkan Undang- 
Undang Nomor 11 Tahun 2012 tentang Sistem Peradilan Pidana Anak ("UU SPPA"), paling lama $1 / 2$ (satu perdua) dari maksimum ancaman pidana penjara bagi orang dewasa.

Tindak pidana penganiayaan diatur dalam Pasal 351 Kitab UndangUndang Hukum Pidana(“KUHP”)sebagai berikut:

(1) Penganiayaan diancam dengan pidana penjara paling lama dua tahun delapan bulan atau pidana denda paling banyak empat ribu lima ratus rupiah.

(2) Jika perbuatan mengakibatkan luka-luka berat, yang bersalah diancam dengan pidana penjara paling lama lima tahun.

(3) Jika mengakibatkan mati, diancam dengan pidana penjara paling lama tujuh tahun.

(4) Dengan penganiayaan disamakan sengaja merusak kesehatan.

(5) Percobaan untuk melakukan kejahatan ini tidak dipidana.

Namun terkadang apa yang dilakukan oleh guru, tenaga pendidik maupun dosen dan lain-lain dalam menjalankan tugasnya untuk melaksanakan pendidikan dan pengajaran serta tuntutan profesionalisme nya tidak jarang mengalami dilematis.Di satu sisi, mereka dituntut untuk mampu mengantarkan peserta didik mencapai tujuan pendidikan. Namun di sisi lain, tatkala para tenaga pendidik berupaya untuk menegakkan kedisplinan, mereka dihadang oleh Undang-Undang Perlindungan Anak dan Komisi Perlindungan Anak Indonesia. Jika mereka gagal menegakkan kedisiplinan peserta didiknya dan gagal mengantarkan peserta didik pada pencapaian tujuan pendidikan, sebagai pendidik acapkali dituding menjadi penyebab atas kegagalan tersebut. Persoalan yang paling krusial dihadapi adalah tatkala mereka harus memberikan hukuman kepada peserta didik yang melanggar tata tertib dan aturan sekolah dalam rangka menegakkan kedisiplinan, acapkali orang tua dan masyarakat menilainya sebagai tindakan melanggar hak asasi manusia atau melanggar UU Perlindungan Anak. Mereka dengan mudahnya melaporkan tindakan guru tersebut kepada penegak hukum (baca: polisi atau KPAI). Akibatnya, dalam menjalankan tugas profesinya guru seringkali berada pada posisi dilematis dan bahkan rentan untuk dikriminalisasi.

Perlindungan terhadap profesi guru sendiri sebenarnya sudah diakui dalam PP (Peraturan Pemerintah) Nomor 74 Tahun 2008. Berikut pasal terkait perlindungan guru:

Pasal 39 ayat 1 dan 2: "Guru memiliki kebebasan memberikan sanksi kepada peserta didiknya yang melanggar norma agama, norma kesusilaan, norma kesopanan, peraturan tertulis maupun tidak tertulis yang ditetapkan guru, peraturan tingkat satuan pendidikan, dan peraturan perundang-undangan dalam proses pembelajaran yang berada di bawah kewenangannya." "Sanksi tersebut dapat berupa teguran dan/ atau peringatan, baik lisan maupun tulisan, serta hukuman yang bersifat mendidik sesuai dengan kaidah pendidikan, kode etik guru, dan peraturan perundang-undangan." 
Pasal 40: "Guru berhak mendapat perlindungan dalam melaksanakan tugas dalam bentuk rasa aman dan jaminan keselamatan dari pemerintah, pemerintah daerah, satuan pendidikan, organisasi profesi guru, dan/atau masyarakat sesuai dengan kewenangan masing-masing.

Pasal 41: "Guru berhak mendapatkan perlindungan hukum dari tindak kekerasan, ancaman, perlakuan diskriminatif, intimidasi, atau perlakuan tidak adil dari pihak peserta didik, orang tua peserta didik, masyarakat, birokrasi, atau pihak lain."

Sebaliknya disekolah Anak di dalam lingkungan sekolah wajib mendapatkan perlindungan dari tindak kekerasan dalam bentuk apapun dari pendidik, tenaga kependidikan, sesama peserta didik, dan/atau pihak lain.jika kekerasan itu terjadi terhadap siswa/ murid/ anak, berdasarkan UndangUndang Nomor 23 Tahun 2002 tentang Perlindungan Anaksebagaimana telah diubah oleh Undang-undang Nomor 35 tahun 2014 tentang Perubahan Atas Undang-Undang Nomor 23 Tahun 2002 tentang Perlindungan Anak dan telah diubah kedua kali dengan Peraturan Pemerintah Pengganti Undang-Undang Nomor 1 Tahun 2016 tentang Perubahan Kedua Atas Undang-Undang Nomor 23 Tahun 2002 tentang Perlindungan Anak yang telah ditetapkan menjadi undangundang oleh Undang-Undang Nomor 17 Tahun 2016 tentang Penetapan Peraturan Pemerintah Pengganti Undang-Undang Nomor 1 Tahun 2016 tentang Perubahan Kedua Atas Undang-Undang Nomor 23 Tahun 2002 tentang Perlindungan Anak Menjadi Undang-Undang.

Pasal 54 Undang-Undang Nomor 35 tahun 2014 tentang Perubahan Atas Undang-Undang Nomor 23 Tahun 2002 tentang Perlindungan Anak ("UU 35/2014") menyatakan:

(1) Anak di dalam dan di lingkungan satuan pendidikan wajib mendapatkan perlindungan dari tindak kekerasan fisik, psikis, kejahatan seksual, dan kejahatan lainnya yang dilakukan oleh pendidik, tenaga kependidikan, sesama peserta didik, dan/atau pihak lain.

(2) Perlindungan sebagaimana dimaksud pada ayat (1) dilakukan oleh pendidik, tenaga kependidikan, aparat pemerintah, dan/atau Masyarakat.

Itu artinya, anak di dalam lingkungan sekolah wajib mendapatkan perlindungan dari tindak kekerasan dalam bentuk apapun dari pendidik, tenaga kependidikan, sesama peserta didik, dan/atau pihak lain. Jadi Guru sebagai tenaga pendidik tidak seharusnya melakukan tindakan kekerasan terhadap anak di sekolah.

UU 35/2014 telah mengatur bahwa setiap orang dilarang menempatkan, membiarkan, melakukan, menyuruh melakukan, atau turut serta melakukan kekerasan terhadap anak. Bagi yang melanggarnya akan dipidana dengan pidana penjara paling lama 3 (tiga) tahun 6 (enam) bulan dan/atau denda paling banyak Rp72 Juta.

Berikut selengkapnya bunyi Pasal 80 jo. Pasal 76C UU 35/2014:Pasal 80 UU 35/2014:

1) Setiap Orang yang melanggar ketentuan sebagaimana dimaksud dalam Pasal 76C, dipidanadengan pidana penjara paling lama 3 (tiga) tahun 6 
(enam) bulan dan/atau denda paling banyakRp72.000.000,00 (tujuh puluh dua juta rupiah).

2) Dalam hal Anak sebagaimana dimaksud pada ayat (1) luka berat, maka pelaku dipidana denganpidana penjara paling lama 5 (lima) tahun dan/atau denda paling banyak Rp100.000.000,00(seratus juta rupiah).

3) Dalam hal Anak sebagaimana dimaksud pada ayat (2) mati, maka pelaku dipidana dengan pidanapenjara paling lama 15 (lima belas) tahun dan/atau denda paling banyak Rp3.000.000.000,00 (tigamiliar rupiah).

4) Pidana ditambah sepertiga dari ketentuan sebagaimana dimaksud pada ayat (1), ayat (2), dan ayat(3) apabila yang melakukan penganiayaan tersebut Orang Tuanya."

Berdasarkan aturan-aturan yang kami jelaskan di atas, maka tindakan kekerasan fisik sebagaimana digambarkan dalam kasus ini adalah tindakan yang sama sekali tidak diperbolehkan, dan merupakan tindakan yang bertentangan dengan peraturan dan hukum yang berlaku.

\section{KESIMPULAN DAN SARAN}

Penganiayaan guru oleh siswanya tentunya tidak sebentar prosesnya. Tidak adanya wibawa guru dimata muridnya dan terbentuknya pribadi yang tidak memiliki rasa hormat terhadap terhadap gurunya karena orientasi belajar hanya mengarah ke pembentukan kecerdasan belaka akan mendorong anak tidak memiliki rasa hormat kepada gurunya. Terjadinya kekerasan yang dilakukan oleh siswa/ murid dan bahkan dilakukan juga oleh orangtua siswa kepada guru. Kedaan ini menunjukan bahwa ada pergeseran moral yang terjadi pada masyarakat, serta keprofesian guru yang semakin tidak ada harganya.

Tindakan peserta didik/murid ini yang melakukan kekerasan kepada gurunya dengan ini dapat dikenakan pidana atas dasar penganiayaan. Namun, pidana penjara yang dapat dijatuhkan kepada Anak, berdasarkan UndangUndang Nomor 11 Tahun 2012 tentang Sistem Peradilan Pidana Anak ("UU SPPA").

Namun jika orangtua siswa yang melakukan penganiayaan terhadap guru/ tenaga pendidik maka dapat diterapkan sesuai dengan ketentuan yang telah ditetapkan dalam Kitab Undang-Undang Hukum Pidana pasal 351.

Adapun saran yang dapat penulis berikan yakni Bagi seorang murid yang ingin mendapatkan ilmu dan ilmunya berguna suatu saat nanti maka murid harus menghormati guru serta taat kepadanya.

\section{REFERENSI}

Kitab Undang-Undang Hukum Pidana;

Undang-Undang Nomor 14 Tahun 2005 Tentang Guru Dan Dosen;

Undang-Undang Nomor 11 Tahun 2012 Tentang Sistem Peradilan Pidana Anak; Undang-Undang Nomor 35 Tahun 2014 Tentang Perubahan Atas UndangUndang Nomor 23 Tahun 2002 Tentang Perlindungan Anak.

Adami Chazawi, Pelajaran Hukum Pidana, Jakarta : Raja Grafindo Persada, 2010 
Bambang Waluyo, Penelitian Hukum Dalam Praktek, Jakarta: Sinar Grafika, 2002.

Barda Nawawi Arif, Bunga Rampai Kebijakan Hukum Pidana, Jakarta, PT.Raja Grafindo Persada, 2010.

Lamintang, Dasar-dasar Hukum Pidana Indonesia, Jakarta, Citra Aditya, 2011.

Moeljatno, 2007, KUHP (Kitab Undang-undang Hukum Pidana), Jakarta, BumiAksara.

Soerjono Soekanto, Pengantar Penelitian Hukum, Ui Press, Jakarta, 1984. 